\title{
Nō Ōrākau: Past and People in James Cowan's Places ${ }^{1}$
}

\author{
ANNABEL COOPER
}

\begin{abstract}
In tracing the interconnections of place and people in James Cowan's writing, this article argues that his widely-disseminated body of work complicates current orthodoxies and warrants more consideration in the study of settlement than it has had to date. Analyses of newspaper features and short non-fiction narratives, and of book chapters which centre on the prototype for Cowan's cultural landscapes, Örākau, provide the basis for an argument that even in an era when the picturesque appeared to have wrought a division between scenic and inhabited landscapes, Cowan's writing refused that distinction. The landscapes he wrote were peopled, valued for their beauty but given meaning by the traditions and the histories attached to them. I argue here that a consideration of Cowan as "nō Ōrākau"-haunted by a place to whose long historical resonances he responded over the work of a lifetime-introduces a more nuanced account of a settler imaginary which can allow not only of subjects who were "seeing men" seeking to possess what they surveyed, but also of those who lived in a complex and discomforted relationship to the indigenous past of place.
\end{abstract}

Formed in the soil of raupatu, James Cowan spent a lifetime reflecting on his origins. In 1870, when James was six months old and while Te Kooti's War was still being fought out across the central North Island, the Cowan family took up a farm in the Waipa Valley. Six years earlier it had been violently wrested from its tangata whenua and their allies in a battle that had almost immediately become one of the most famous of the New Zealand Wars: Ōrākau. From a childhood at Ōrākau in the decades after the battle, absorbing its past from the tangible evidence of the landscape itself as well as from the tales of former warriors and soldier-settlers, Cowan went on to a lifetime of persistent return to colonial conflict and encounter. His work rehearsed their significance across journalism, history, and non-fiction yarns, and from shifting perspectives. This article discusses Cowan's "battleground of home" as a defining landscape which shaped his conception of the presence of the past in place.

Cowan's productive years, from the late 1880s to around 1940, fell well after "contact" in New Zealand, but in his childhood and then in his working life he lived between Pākehā and Māori worlds. His second marriage in 1913, to Eileen Stowell who was of Ngāpuhi, Te Āti Awa and Pākehā descent, added a further dimension to his place on this cultural border. ${ }^{2}$ The many journeys and encounters in which his work involved him located him in what Mary Louise Pratt has called "the contact zone ... the space of colonial encounters, the space in which peoples geographically and historically separated came into contact with each other and established ongoing relations." 3 Cowan was clearly constituted by his relation to Māori and his feeling for place was shaped by this relationship. Yet, to pursue Pratt's discussion further, I shall argue that Cowan should not be understood as a "'seeing-man,' ... the European male subject of European landscape discourse- he whose imperial eyes passively look out and possess." 4

He might perhaps have become such a figure. Giselle Byrnes has shown how through the middle and latter parts of the nineteenth century the gaze of surveyors upon the land facilitated obtaining and settling, and that colonial surveying and conceptions of landscape frequently operated symbiotically through visual strategies to produce "cultural space" opened to conceptual and then literal possession. Byrnes sets out the case for attention "to the ways in which European settlers attempted to legitimise their presence in the colony 
through the construction of cultural space." Geoff Park has pointed out that the $1890 \mathrm{~s}$ - the years of Cowan's early career-were a "moment for landscape" in New Zealand. He argues that the Land Act (1892) and then the Scenery Preservation Act (1903) had complex motivations and effects: while they signalled the threatened condition of many landscapes (including places of historic significance for both cultures), they also, effectively, legislated in favour of the European tradition of the picturesque, at the same time undermining Māori tenure. It was during this "moment," Park argues, that the distinction between inhabited and wild landscape came to be understood as absolute: land would be either the site of human activity and habitation, in the domain of culture, or wilderness, in the domain of nature, and in need of protection from despoliation by human occupation. Indigenous dispossession was a necessary result of new conceptions of landscape and the rise of scenic tourism. ${ }^{6}$

James Cowan's first job, held between 1888 and 1902, was as a journalist on the Auckland Star. ${ }^{7}$ Because of his fluent Māori and his early interest in Māori-Pākehā history, he was frequently given stories relating to Māori history and culture-stories which fell often into the category of travel journalism. He rapidly became known for this work, and his next position was as a writer for the newly-established Department of Tourist and Health Resorts. Over the next five decades, in this role and then as a freelance travel writer, Cowan turned out features on popular tourist destinations like Rotorua and Waikaremoana or lesser-known byways in the remote corners of bush or coast. He wrote for a rising market of rail, road and armchair travellers. His writing on Māori, travel and New Zealand history was syndicated across several regional newspapers, and in later decades he wrote regular features for the very widely-read New Zealand Railways Magazine.

Cowan certainly spoke the narratives of settler progress; the future lay in farming prosperity. His Travel Guide to the North Island (1926), for example, anticipates the day when green farms would spread from the Waipa to Taranaki, just as they swept down into the King Country once the aukati gave way after $1883 .{ }^{8}$ But this was not his dominant note. This article will argue - as Lydia Wevers does also in this issue - that even where this strain appears in Cowan's writing it is curtailed by ambivalence, and frequently a critical reflectiveness about colonisation and his own place in it. This reflectiveness was expressed in an underlying conception of landscape usually at odds with the prevailing character of the travelogue, the vignette, or the popular feature. Cowan the historian regularly interrupted Cowan the travel writer; and narratives of memory repeatedly complicated the scenic perspective. This is not surprising, since his commissions resulted from his very familiarity with colonial history, particularly as it related to place. Many of the new tourist regions to which his work took him - such as Te Urewera and the thermal regions of the central and eastern North Island - had been the sites of earlier conflict, and his childhood interest in the Wars both shaped and was enriched by his visits to these areas.

My argument here is that a careful reading of Cowan's work must complicate the prevailing critique of settler imaginaries in Aotearoa New Zealand. Studies of settlement read the Pākehā writing of this era as operating almost inevitably to both legitimate and forget indigenous dispossession; and generally categorise reference to Māori cultural material under the rubric of appropriation. While this was undoubtedly the dominant strain, it is striking that at least until this special issue, only a very partial reading of Cowan's work has emerged in this critique, and often Cowan rates no mention at all. ${ }^{9}$ This may be partly because the popular literature and journalism which formed much of his output is categorised as neither history nor literature and therefore fails to catch the eye of either historians or critics. Yet Cowan's writing nudged, prompted and at times pushed his readers to confront the knowledge of indigenous displacement. Combined with its abundance and wide dissemination, this emphasis argues for more sustained attention. His relative absence from critical discussion to date is all the more compelling because of the frequency with which 
Cowan's work was commissioned, published, republished-and read-in magazines, newspapers, and books; for decades after his death, in that shaper of young minds, the School Journal; and in the four collections of short non-fiction pieces which had their place on many a New Zealand bookshelf from the 1930s and 40s. ${ }^{10}$ More than any other writer on Māori and Māori-Pākehā subjects writing at the time, his work had a broad "throw."11 With such support from editors, publishers and readers throughout the first half of the twentieth century and even beyond, he can hardly have been completely out of tune with the times.

I'd like to return at this point to my earlier reference to Mary Louise Pratt's idea of the colonial traveller as a "seeing-man." Jessica Dubow has argued against what she sees as a narrow scopic emphasis in the work of Pratt and other scholars associated with the first wave of postcolonial critique. In seeking to revisit the slogan that "vision amounts to colonization," Dubow brings:

a degree of qualification to that interpretative approach which conceives representations of colonial space and sight as the symbolic analogue of the politics of European territorial expansionism. ${ }^{12}$

Her argument for "a more dialogic conception of colonial sight and space," understanding colonial subjects as living "in place and through perception," 13 offers a rich and highly appropriate entree into Cowan's approach to place. His own favoured modes of travel suggest this kind of "lived and affective" engagement: although he wrote for train travelers and then for the beginnings of motor tourism, he greatly preferred to travel by horse or water, both of which slowed the pace and invited company, preferably of the tangata whenua. His methods and his approach as, always, a latecomer ensured that he encountered places replete with meaning and history. Frequently commissioned to produce a landscape which his readers could visualise, he persistently returned with an audible one. No terra nullius here, waiting for colonising eyes to bestow form and meaning: these landscapes had long been full of stories, even if they were losing their people.

By 1910, in a 12-part series of features on "Old Rotorua: Legends of the Lakes" written for the Evening Post, Cowan had developed his practice of framing an article with reference to a named Māori informant. In these articles he takes up with a series of companions who walk him around Rotorua and its surroundings and tell him about many sites, their "folk-lore," the settlements or buildings that used to be there, and especially about people and events from the site's past. It is a conventional rhetorical device but the interlocutors' authority, their knowledge of the past and the context of shared activity and conversation through which knowledge is communicated, is reiterated frequently:

Old tattooed Kiharoa and I sat smoking one blue day on the fern-grown earthworks of the Maharo redoubt where the Pakeha flagstaff now stands, in the "tihi" or citadel of famous Pukeroa ... in the olden days the capital of the NgatiWhakaue tribe....

"What is the meaning of the name Whakarewarewa?" is a question that is often asked ... an old Tuhourangi chief, Mita Taupopoki, gives me the explanation of the name....

We were sailing across Lake Rotorua, Taua Tutanekai and I, bound from Ohinemutu to Mokoia Island.... ${ }^{14}$

The same series includes a passage in which, sleeping out, he looks to the sky and names the stars, beginning with their Māori names and then translating for the benefit of those unaware of their original namings: 
... glittering Rehua, the "Dogstar" Sirius. Meremere-tu-ahiahi, the bright evening star ... brightly winkling Whakaahu and his fellow of the Twins, which the Oldworld astronomers named Castor and Pollux... ${ }^{15}$

In a much later feature ("Lakeland and Storyland: The Charm of a Rotorua Cruise") for the Railways Magazine, which mined the research for the Evening Post series, Cowan and "a capital Maori mate," Tamarahi, travel around Rotoiti. Tamarahi's detailed knowledge of the weather patterns and the winds guides them, "sailing or paddling from bay to bay, making the acquaintance of the small communities of the Ngati-Pikiao tribe who lived in the lovely indents of Rotoiti's in-and-out coast." "Real unspoiled bush" is not defined by the absence of habitation, but imbued with reference to its human past and present:

There is a rocky isle, Pateko, half-way down the lake, a place of legend and elegiac poem. Long ago it was a fort and a refuge; nowadays it is the burial place of the small hapus who live on the nearby southern shore of Rotoiti. ${ }^{16}$

As Michael King and Chris Hilliard have both observed, Cowan's writing is peppered with reference to the "old-time Maori." King views these references as a way of keeping the past in the past: "Cowan tended to view his elderly informants as survivors from a pristine age, as men and women who exemplified worthy features of Maori life destined for imminent extinction." 17 Nevertheless, the presence of these speakers also serves another purpose, in anchoring a specifically indigenous past in the land. Although Māori are part of the "local flavour" in passages such as those quoted above, they are also the sources of knowledge and provide its context. Persisting across Cowan's writing is an emphatic insistence on the presence of the past in landscape, and particularly, on iwi occupation, practice, knowledge and ownership. Commissioned as travelogues and widely-read, these feature articles document not the uninhabited scene but landscapes densely inscribed with cultural significance.

When Cowan republished material, he sometimes drew quite a different narrative thread out of the same journey, but still, his named companions provide the landscape's history and thereby locate its meaning. He wrote about the Rotoiti trip with Tamarahi, for example, for the collection Tales of the Maori Border. This time Cowan recorded Tamarahi's narrative of how a piece of land was transferred from one hapū to another. The story provides an account of practices of warfare but also interprets an exchange between two chiefs in which they negotiate protocols to avoid further conflict. Tamarahi is the descendant of one of these chiefs; he recalls the event as a familiar story which elaborates the meaning of the place and his own belonging as he sails by with Cowan, beginning with the passing comment that:

That old pa up there ... is one of my burial places. I can lie there if I like, when I die, or at Taheke yonder, or at Pukurahi across the lake, or on Pateko, that little island down the lake, and of course, at Maketu. Oh, I've lots of land for my grave.

Cowan concludes the story by marking the depth of the past attached to place and underlining the continuity of occupation: "And from the chief Te Takinga, who was the son of Pikiao, in direct descent to my cruising mate who told the story, it was ten generations of men." 18

A different kind of newspaper story also testifies to the priority Cowan accorded to tangata whenua conceptions of and relationships to landscape. On several occasions he engaged in debate on local matters that related to the links between tangata whenua and place. One example, which testifies to a conception of "wilderness" as already-occupied, is an item entitled "Opening up Urewera," from 1921. In this article, written at a time when the Crown was embarking on development with arguable benefit to local iwi, Cowan is reported 
as speaking "most emphatically" against opening up Te Urewera for "settlement." He argues for the strict preservation of the forest, but also for continued occupuation by tangata whenua, seeing no conflict of interest between them. ${ }^{19}$

A second example is striking for Cowan's insistence that naming should express tangata whenua conceptions of landscape features. In an article objecting to a proposal to rename the Tongariro River the "Upper Waikato," he objects to the lack of "sound geographical reason." He affirms first that the change flouts "local Maori and pakeha usage," but as he warms to his theme it is increasingly apparent that the lack of geographical reason lies in the new proposal's inconsistency with the logic of the original naming. He concludes with an exasperated emphasis on the reasons for the existing name, but just as important is the authority of the namers:

... by far the greatest part of the water discharged into Lake Taupo by the Tongariro River comes from the Tongariro Range. That is why the Maoris so named the river. Whenever I have spoken with the Maoris on the spot about place names in the National Park region it was always the Tongariro River; never the Waikato. $^{20}$

Why get this so wrong, he grumbles, when Māori are perfectly clear about the name?

I'd like to turn from these general points about Cowan's journalism to discuss just one landscape. Almost anyone who wrote about Cowan mentioned the landscape of his boyhood and he reiterated it frequently himself. If as Nigel Thrift has contended, "places are passings that haunt us," Orākau was a "passing," a nexus of memories which most certainly haunted Cowan. ${ }^{21}$

By the time the infant James arrived in Ōākau it was already a place deeply embedded in public memory. For Pākehā the terms had been set by Edward FitzGerald's passionate editorial in the Press, days after the battle in April 1864. FitzGerald's accusation that "it was a war dictated by avarice and prosecuted for spoliation ... to destroy a race that we might dwell in their tents" did not find substantial public purchase-indeed FitzGerald himself as Native Minister confirmed the confiscation that followed-but his admiration of Orākau's defenders came to define national understanding of the battle:

the sad spectacle of those grim and tawny figures, gaunt with the watching and the weariness, the wounds and nakedness of a long campaign in the bush, staring over their ragged palisades on the hosts of the conquerors from whom escape was impossible, and wailing out their last chant of death and defiance-ake, ake, ake-for ever! for ever! for ever! ${ }^{22}$

The remaining part of this article attempts, through a discussion of chapters in two books Cowan wrote in 1922, to excavate the significance for Cowan of being $n \bar{o} \bar{O} r \bar{k} k a u$, both from and of Ōräkau. These chapters need to be read for, and in the light of, the strong emotion with which Cowan approached the subject of Ōrākau. I will argue that chapters 38 and 39, on "The Siege of Ōrākau" in The New Zealand Wars, written for a national, bicultural readership, stand somewhat apart from the rest of the volume in effecting a rhetorical return of Cowan's childhood home to its former defenders. The Old Frontier, a local history of the Waipa, covers the battle in a more conventional fashion, but its treatment of the period of Cowan's childhood in chapter twelve, "Pioneer Life on the Old Frontier," can be read as a complement to, or explanation of, the Ōrākau chapters in the official history, in that it elaborates a memory of a childhood place in which the past was haunting indeed. ${ }^{23}$

Cowan's official history is an unusual example of the genre for its time, in the balance it achieves between government and resistant perspectives on the New Zealand Wars. From its inception (as his initial proposal shows) Cowan had envisaged the constituency of the official history as including Māori, from resistant as well as Crown-allied iwi and hapū, 
as well as Pākehā. ${ }^{24}$ The inclusiveness he imagined for the readership was mirrored in his conception of the book's purpose - to tell the Wars from all sides - and the practice of his research, which was informed by his journalism and relied primarily on oral testimony.

As has often been noted, he found people who had fought on all sides in the various engagements and where possible he interviewed them on the sites of the conflicts, reconnecting them to the land they fought over in order to prompt their memories of what had taken place there. ${ }^{25} \mathrm{~A}$ number of his field notebooks for the Wars project survive. The interviews are recorded at speed, sometimes in shorthand, and they move rapidly between languages, following the language of the informants across Māori and English. When he notes a question asked of a Māori informant, it too is in Māori, suggesting his close following of informants' narratives. Sketches of fortifications and landscapes are interspersed between them. ${ }^{26}$ When these accounts were brought into the final form of the history, their detailed quotation resulted in a constant crossing of lines and shifting of perspectives. Often, tangata whenua narratives reached back into the longer past. In part through this method and in part through the conversations which Cowan's knowledge, experience and interest facilitated, tangata whenua attachment to place, and a broader sense of the layered past of place, were brought across from his travel journalism into a work of greater historical depth.

Even in this unusual military history, the chapters on the Battle of Örākau in The New Zealand Wars stand out. With the exception of some space given to Von Tempsky's record ${ }^{27}$ near the beginning, and later to William Mair, the government interpreter, these two long chapters are told almost entirely from the defending side: less than six of the forty pages come from government-aligned records.

Two evocative passages on the landscapes of Māori settlements prior to the invasion precede the narrative of the Battle of Ōākau. The first of these passages is in chapter 37, bluntly entitled "The Invasion of Rangiaowhia." The chapter describes the decisive night march which circumvented the massive fortification of Pāterangi, in order to attack the supply source, rather than the defences, of the resistant forces. The attack has been contentious ever since, because Rangiaowhia was undefended, and inhabited by women, children and elderly only. The exact events are contested, but whares, and perhaps a church, were burned, and the inhabitants fired upon. Cowan's long first paragraph of the chapter on Rangiaowhia follows the point of view of the invading troops, but the scene as he describes it undermines the justification for invasion. Instead, as they near the village, the troops come upon a landscape resonant with familiar tropes of settled peace:

the large unfortified settlement of Rangiaowhia came in sight, a scene of peace and beauty. Fields of wheat, maize, and potatoes extended over long gentle slopes, and peach-groves shading clusters of thatched houses were scattered along a green hill trending north and south, the crown of the village, with the steeples of two churches rising above the trees, a quarter of a mile apart. In the swampy and part-wooded valley of Pekapeka-rau, below on the left as the invading army marched along the southern rim of the Rangiaowhia basin, the morning mists curled up from the raupo-bordered waters of a little lagoon, the dam which supplied the power for a flour-mill. ${ }^{28}$

Except for the few Māori words, the passage might just as readily be describing an English village, with its crops and peach-trees, thatching, steeples, wooded valley and morning mist. Nothing in the account of the settlement seems to warrant attack. While Cowan's record of the attack on Rangiaowhia seems relatively uncritical to present-day eyes, this evocation of harmonious calm in the likeness of rural England nevertheless does its work to question the attack on the non-combatants as they rush to the whares and churches for defence. 
The rural idyll and the fertile landscape of Rangiaowhia are reiterated when Cowan turns to the landscape of home in the first of the Ōrākau chapters:

Three miles to the east of General Cameron's advanced post at Kihikihi the village of Orakau ("the Place of Trees") lay among its fruit-groves and its cultivated fields, gently tilted to the quarter of greatest sunshine. ${ }^{29}$

Ōrākau too is "a collection of thatched hamlets," settled in a gentle landscape whose features are named one after the other. The second paragraph begins emphatically with "Orakau was an idyllic home for the Maori," then lists the many varieties of produce grown in this "garden of fruit and root crops." The prelapsarian world is gone, but still evocative in memory, and Cowan specifies the hapu of the tangata whenua:

"Ah," said old Tu Takerei, of Parawera, who was born in Orakau, "it was indeed a beautiful and fruitful place before the war. The food we grew was good and abundant, and the people were strong and healthy - there was no disease among them; those were the days of peace, when men and women died only of extreme old age."

The people of Orakau were the Ngati-Koura hapu of Waikato, with a section of Ngati-Raukawa. ${ }^{30}$

The productivity and peace of the pre-war years when Māori grew and traded European crops situate the account that is to follow. At this point in the chapter only one small and bracketed detail, referring to the knoll where the Māori church stood, signals the outcome of the battle and its consequence. Through it Cowan locates his connection with the landscape to come:

(On this elevation Mr. W.A. Cowan, father of the present writer, built his homestead a few years after the battle.) ${ }^{31}$

The pre-war setting established, the chapter turns to its subject. The account of the fortifying and then the siege begins with an initial foray by the government troops. ${ }^{32}$ Then, the chapter turns to the defending side and now a different kind of narrative predominates: there is the occasional interruption from the government side but from here on, the chapters are heavily weighted not only towards information from the defending side, but towards the kind of information which Māori more than Pākehā would have considered relevant. It includes accounts of the series of meetings between different hapu and iwi to decide on the next move of the defending campaign, the debates and then the meeting with the group from Te Urewera who persuaded Rewi Maniapoto and the other allied chiefs to fight at Ōrākau, and names and iwi affilations are set out in detail. The narrative cycles back into the history of obligations between iwi lying behind this encounter, showing why events then took the course they did. It recounts Rewi's attempt to prevent the battle at this site, and the arguments he put forward against it, including his prophetic dream foretelling its failure. Then follows the design and preparation of the earthwork, the iwi of the defenders, and which of them defended each part of the pā, including the names and iwi of the leaders. Some warriors are described in detail, including their religious affiliations. The story, in brief, proceeds according to Māori understandings of warfare and what should be remembered of warfare.

Now comes a shift back to the attacking side, with the discovery of the pā by two government surveyors, and the narrative moves back and forth between sides as the assault is recounted. As part of these events, the haka and peruperu performed are recorded. Then there is a long narrative from Te Huia Raureti, Cowan's most important informant on Ōrākau, whom he interviewed at length on 27 May 1920, but had known since boyhood. Later more named informants from the defenders come in-Hitiri te Paerata and Te Winiata Tupotahi 
(Cowan had also known Tupotahi as a child). The first chapter is increasingly given over to these first person accounts as more defenders are named and their narratives given.

The second chapter incorporates new defending voices-Pou-patate, Peita Kotuku, and Te Huia again - with one first-person account on the government side only, that of the interpreter William Mair, which is set off as a discrete section in a smaller font. The breakout from the pā- the climactic event - is narrated dramatically through a first person account by Rewi Maniapoto himself:

Many years after the war, standing on the sacred soil of Orakau pa, he gave a narrative of the siege... "When we rushed out of the pa," said Rewi, "I prayed to God. The words of my prayer were, 'E Ihowa, tohungia ahau, kaua e whakaekea tenei hara ki runga i a au...' Just then I stumbled and fell down, which made me very dark in my heart, for it was an evil omen." 33

It is possible that Cowan recorded this account personally, as Rewi died in 1894 when Cowan was about twenty-four, but perhaps more likely that Rewi's account was told to Cowan by Te Huia Raureti or another close associate.

It is unusual in The New Zealand Wars to find the narrative so heavily weighted on one side when there were accounts from both, and many accounts of this battle existed. Cowan plainly elected to tell it from the defenders' perspective, and the rising intensity of the narration reveals it as a highly crafted account. Having located himself as a direct beneficiary of the defeat in the earlier, bracketed, sentence, he now cedes moral claim, establishing an enduring connection between the defenders and the landscape of memory.

The Old Frontier, a local history published by the Waipa Times in Te Awamutu, was designed for "the younger generation of colonists, and the now large population on both sides of the old Maori border": a settler readership, in contrast to Cowan's more inclusive intentions for the Wars history. ${ }^{34}$ Now that those settlers who had lived through the events of the Wars and their immediate aftermath were passing on, he noted, this new generation knew little of the past associated with "the familiar home landscapes." Later in his life, this observation would become a complaint that the Waikato farmers were "an ignorant lot." 35 But for now, Cowan undertook to remind the new occupants that the serene landscape had once had different inhabitants, locating the war within an account of longer changes in land and landscape, occupation, use and attachment.

The Old Frontier is not one of Cowan's best books, and was plainly a quick project designed to make some extra income from his work on the Wars. Its cut-and-paste construction, partly from Cowan's own journalism and historical work, partly from a variety of sources some of which were also cited in the official history, pieced together with purposewritten chapters and sections, does not make for fine history but it does lay bare in a particularly striking way the bricolage of Cowan's historical sensibility.

The introduction retells "myths and legends" of the landscape, including stories of the mountains and some brief notes on earthworks remaining from the pre-European period. Looking back on the landscape of his boyhood Cowan aligns himself with tangata whenua love of the landscape:

I came to look on that lone mountain with very much the kind of affection in which it is held by the Maori people who live around its base, whose local folklore and poetry enshrine many a reference to Kakepuku. ${ }^{36}$

At the same time, Cowan signals a prosperous future for the younger colonists: the land is "promising as a land of fat stock and good crops, of dairy herds and meat." 37 In these first few chapters, the volume largely speaks, therefore, to the audience identified in the preface: a 
new settler generation, looking forward to a future of prosperous farming, willing perhaps to be entertained by the mythological past.

Most of the volume covers the pre-war missionary settlement period and then the war, with several additional "aftermath" chapters. The missionary era and particularly the long residence and influence of the Reverend John Morgan, the introduction of plough and flour-mill, and the establishment of gardens, grain crops and orchards on the fertile Waipa land draw heavily on missionary records. Extending the evocative descriptions of pre-war Rangiaowhia and Ōrākau included in the official history back into the pre-war era, these chapters register Māori occupation and use as adaptive and ongoing, rather than belonging to an absolute past of "old times." Cowan's account here follows the widespread view of the Waipa in the era of Morgan's mission as a model of the amalgamationist policy; but in doing so it also emphasises the adaptiveness and success of the pre-war Māori economy.

The turn to war begins with a chapter on John Gorst's residency. At this point Cowan's research on the wars is deployed again; here he registers sympathy for the Kingitanga. It was not initially a hostile development, he argues, but entirely consistent with the spirit of productive collaboration elaborated in the preceding chapters. Pākehā treatment of Māori chiefs in the towns and blundering government policy under Gore Browne contributed to "a war feeling in Waikato." 38 As tensions rose, "the conflict was due as much to the aggressive policy of the Government and the anti-Maori tone of the newspapers and the politicians as to the martial preparations of the Kingites." 39 Chapters on Rangiaowhia, Hairini, Kihikihi and Ōrākau are taken almost verbatim from Von Tempsky's manuscript, although the final pages of the chapter on Örākau switch to Te Huia Raureti's narrative, briefly of the defence but mostly on the retreat to the Puniu River after the defenders broke out of the pā. While the account of the war is sympathetic to the defenders, therefore, its heavy reliance on Von Tempsky means that it is told primarily from the invading side. ${ }^{40}$

Two chapters concern the post-war period. Chapter eleven, "Camp Life at Te Awamutu," draws on the record of an army chaplain. Chapter twelve, "Pioneer Life on the Old Frontier," is written from Cowan's own perspective, and returns the reader to the personal affiliation with place which the introduction has signalled. This chapter warrants detailed discussion of the way in which Cowan places himself in the landscape.

Turning from archive to personal recollection and from third to first person narrative, Cowan revisits his own memories of Ōākau in the decade after the Waikato War. The epigraph explicitly compares Te Rohe Pōtae, largely closed to Pākehā during Cowan's childhood, with the Scottish highlands, drawing on the common analogy between Māori and Highland Scots and thereby half-aligning Cowan, given his Scottish-Irish descent, with those "beyond the border." 41

The opening of the chapter proper then sets out a strikingly ambivalent articulation of relationships between land, people and past, as Cowan recalls the view from the northern side of the Puniu River, at that time the aukati or border, south to Te Rohe Pōtae, a view that was necessarily distant. Within a single long sentence he defines with precision the grounds of the Cowan family's presence there, and at the same time the ambivalent but evocative attraction of another world visible but nevertheless intangible:

Looking southward across the Puniu in the Seventies and early Eighties we who were bred up on the Frontier saw a mysterious-appearing land, fascinating to the imagination because unknown - a land, too, of dread in the years of unrest, for there in the hinterland only a few miles from the border river lived Te Kooti and his band and the hundreds of Waikato dispossessed of their good lands on which we Pākehā families now dwelt. ${ }^{42}$ 
This opening proceeds to a protracted balancing act between perspectives that are both scopic and cultural. In the distance the land is "altogether given up to the Kingites and Hauhaus," but these occupants are invisible from afar. South of the Puniu seems, at first, to be a land of scenery: "the dark purple of broken mountain ranges ... the vague, misty blues of great distance, the sombre green of ferny hills and plains...." This Claudian perspective on the far distance is however quickly disrupted by particular detail of the rich resources for tangata whenua, known to the adult Cowan but inaccessible to his child's eye: flax and raupo swamps, and watercourses "alive with eels and wild duck." But then there is a return to the idea - unusual in Cowan's writing — of an "untouched" landscape. Despite those Kingites and Hauhaus, "over all ... an aspect and air of solitude; a suggestion of mystery and waiting for the touch of man which was to transform that far-stretching waste." 43 (My emphasis.). The view on the northern side of the river looks entirely different. Progress reigns:

The contrast! On our side the green farms of the pioneer settlers, roads, villageseach with its redoubt as a rallying-place in alarm — churches, schools - primitive schools, maybe, in the early stages — the flag of British authority flying.

So the border remained, the line of demarcation sharply defined by the confiscation boundary, the southern side inimical, sullen, waiting, for well-nigh twenty years after the final shots of the Waikato War. ${ }^{44}$ (My emphasis.)

This is a complex mix indeed. On the one hand, land in Māori hands is "sullen, waiting," "waste" until it passes into settler hands and can be made into "green farms." The unknown side of the border conceals an ongoing threat in which both landscape and Kingitanga forces are implicated. On the other hand, it is far from clear that the northern side of the border is the more attractive: the "clear, dashing hill-streams and lazy, swamp-born watercourses" with those eels and wildfowl have a more evocative ring than the stolid churches and schools, and it is the southern, not the northern side which "fascinat[es] the imagination."

Nor are the people on the other side of the border in fact unknown. Pākehā could not travel readily into Te Rohe Pōtae, but Māori crossed the aukati often enough:

Maoris were more numerous than Pakehas; many a savage-looking and tattooed warrior, wearing a waist-shawl-for the Maori had not then taken kindly to trousers - called in at the home from one or other of the large villages just over the border; and native labour was employed at times on the farms. ${ }^{45}$

The aukati is a profoundly ambiguous border. The adult and the child's ambivalent perspectives view it both as absolute, with the other side unknown, part threatening, part fascinating; and at the same time as permeable and even sociable. Similarly, Māori are remembered variously as the frightening "Te Kooti and his band," as well as the Waikato, once themselves the farmers and possessors of the "good lands," and as "native labour" wellknown to the settler families. Cowan does not mention here, perhaps an odd omission, that he grew up speaking fluent Māori and that it was in this time that he began his lifelong practice of collecting Māori stories.

On the next page Cowan turns his gaze in recollection to the foreground, as he connects the traces of past habitation on the farm to the land's present productivity. Here the stock phrases of rural childhood nostalgia, many of which like the official history's paeans to Rangiaowhia and Ōrākau might have been lifted straight from stories of the English countryside, are repeatedly interrupted by evidence of previous occupation and the moment of dispossession. The abundance recalled from childhood is fruit of the labour of the people now over the border: 
There was the home on the hill, on the famous battlefield, the garden with its sweet old flowers, the cherry orchard, the huge almond trees (with flat stones at their feet upon which Māori children long before us cracked those almonds) trees grown in the old days from the Rev. John Morgan's orchard-the wild mint that grew in the tiny creek that went rippling down a swampy gully near the big acacia grove; the dam and the lake-like pond in the Tautoro swamp; and, above all, the peaches. The peaches of those happy dream-days on the old Orakau farm!- peaches vanished, a kind never to be tasted by the present generation. Orakau, Kihikihi, Te Awamutu, and Rangiaowhia were then the favoured land of the most delicious fruit that ever this countryside has known. Peach-groves everywhere, the good Màori groves, trees laden with the big honey peaches that the natives called korako because of their whiteness. ${ }^{46}$ (My emphasis.)

The fecundity and semi-wild abundance of the old trees in Cowan's childhood derive from the former owners' industrious horticulture; the enjoyment of the almonds and the peaches were the peaceable privilege of Māori children a generation earlier. Commenting on Michael King, Lydia Wevers observes that "his claim to indigeneity begins, as all stories of nativism do, with childhood and landscape, a comforting internalization connecting innocence and land." 47 In this passage, by contrast, the rhetoric of nostalgia envelops childhood and landscape but the longer past pushes its way insistently in, emphatically over-riding such a claim, and precluding comfort.

The mention of peach trees draws on a motif which had acquired substantial resonance in first-hand accounts of the Wars. Many soldiers' narratives recalled the white peaches, a variety destroyed by blight during the later part of the nineteenth century. To note that battles were fought in or around peach orchards marked a fall from an earlier, peaceable era: Cowan may have been able to taste their fruit in childhood but they were already, metaphorically before literally, "peaches vanished." So Cowan observes how the peach-trees themselves at Ōākau carry the scars of the violent change of ownership:

... nearly every tree bore the curious weals and knotty growths that indicated a bullet-wound, and a search with a knife sometimes revealed a half-flattened ball or fragment of one. ${ }^{48}$

This is a remembered landscape which, whether in the distant views across the river or in the close detail of the knots and weals a child could touch and excavate, moving beyond vision to tactile encounter, derives its meaning from its past. It does not seem a great stretch of the imagination to suggest that Cowan's feeling for this place may have had a quite direct relationship with what became his habitual practice of establishing the meaning of place through its past.

The particular character of Cowan's remembering is perhaps even more compelling in light of its apparent selectiveness. His emphasis on the narrative of fall-the loss of the pre-war Māori agricultural economy and the peaceable co-existence which it represented to him-and his record of the transfer of prosperity to the settlers is somewhat undone by comparison with other sources. St. John, for example, writes of riding through the Waikato in the early 1870s and notes that many military settlers' properties between Ngāruawahia and Pirongia (then Alexandra) had been sold on to speculators who did not know what to do with them: "thousands of acres, formerly supporting a large native population and producing corn in abundance, which have once more returned to a wild state." 49 While this may not have been the case on the northern banks of the Puniu, it does suggest that settler prosperity was not assured, and the "green farms" were not everywhere. At the same time, there was a considerable economic recovery under way in the Rohe Pōtae, where by the late 1860s the 
Kingitanga was again engaged in a substantial export of crops. ${ }^{50}$ What this points to, I suggest, is that The Old Frontier's imagined past may be more a clue to Cowan's complex sensibility than the more mixed historical reality. ${ }^{51}$

In sum, two themes emerge from this volume. First, its insistence on the history of the land - the mythological deep past of the introduction, the pre-war golden era of amalgamation, the fall which was the war, and Cowan's reflections on a childhood spent in a landscape rich and beloved but dense with the scars of conflict-constitutes a direct address to the settler generation not haunted by the past of its place, even if that address is undermined by the prosperous future the volume promises. Second, the first-person chapter twelve, embedded lovingly but uncertainly in the remembered place, complements the rhetorical strategy which I have argued shapes the chapters on Örākau in The New Zealand Wars. If we want to know what went on in Cowan's mind as he gave over the story of Ôrākau to the Kingitanga toa in the official history, this chapter of The Old Frontier offers us as good an insight as any.

Shaped so early and strongly by place, Cowan routinely assumed that land was already "made place." Its meanings were established before Pākehā settlement, and those older meanings and attachments could not be erased. They remained, more or less visible according to the attentiveness of the watcher, the visitor, or the new occupant, demanding recognition.

This article has argued that Cowan's writing about the past of place-an extensive body of work with a broad "throw" - is evidence that Pākehā writing about place was not invariably and exclusively a practice of legitimation. As Chris Hilliard has shown, attention to a figure like Cowan opens up an enriched cultural history: the possibility of a more nuanced and local genealogy of colonial identity, and one in which, rather than settling for an easy superiority towards the history-makers of an earlier era, we might respect the seriousness of the way in which some at least engaged with the conflicts which had so recently and directly shaped their lives. Cowan, who might have settled into a comfortable life on a fertile Waikato farm, opted instead for an often impecunious life of telling Pākehā about tangata whenua.

Writing from the contact zone in 1922, how does Cowan situate himself in Örākau? Rather than a commanding view from afar, we find a series of traces of himself in and out of place. He is a Highlander across the border; he is a child gazing anxiously from the "green farms" to the "mysterious" "sullen" distance; he is the lucky child reaping the harvest of peaches planted by the now dispossessed Waikato; he is the curious child excavating shot from trees whose wounds echo the injuries inflicted on the defenders; he is the listening child absorbing the defenders' stories of the past; he is the young man precipitated, in part by those stories, on his journey away from the farm and into an unsettled, precarious career retelling their histories; and he is the knowledgeable local predicting a solid farming future. This disconnected set of memories and affiliations to place speaks of no easy fit between childhood, land and belonging. To be nō Ōrākau, from and of Ōrākau, means to grow up not with innocent connection, but disturbing knowledge. 


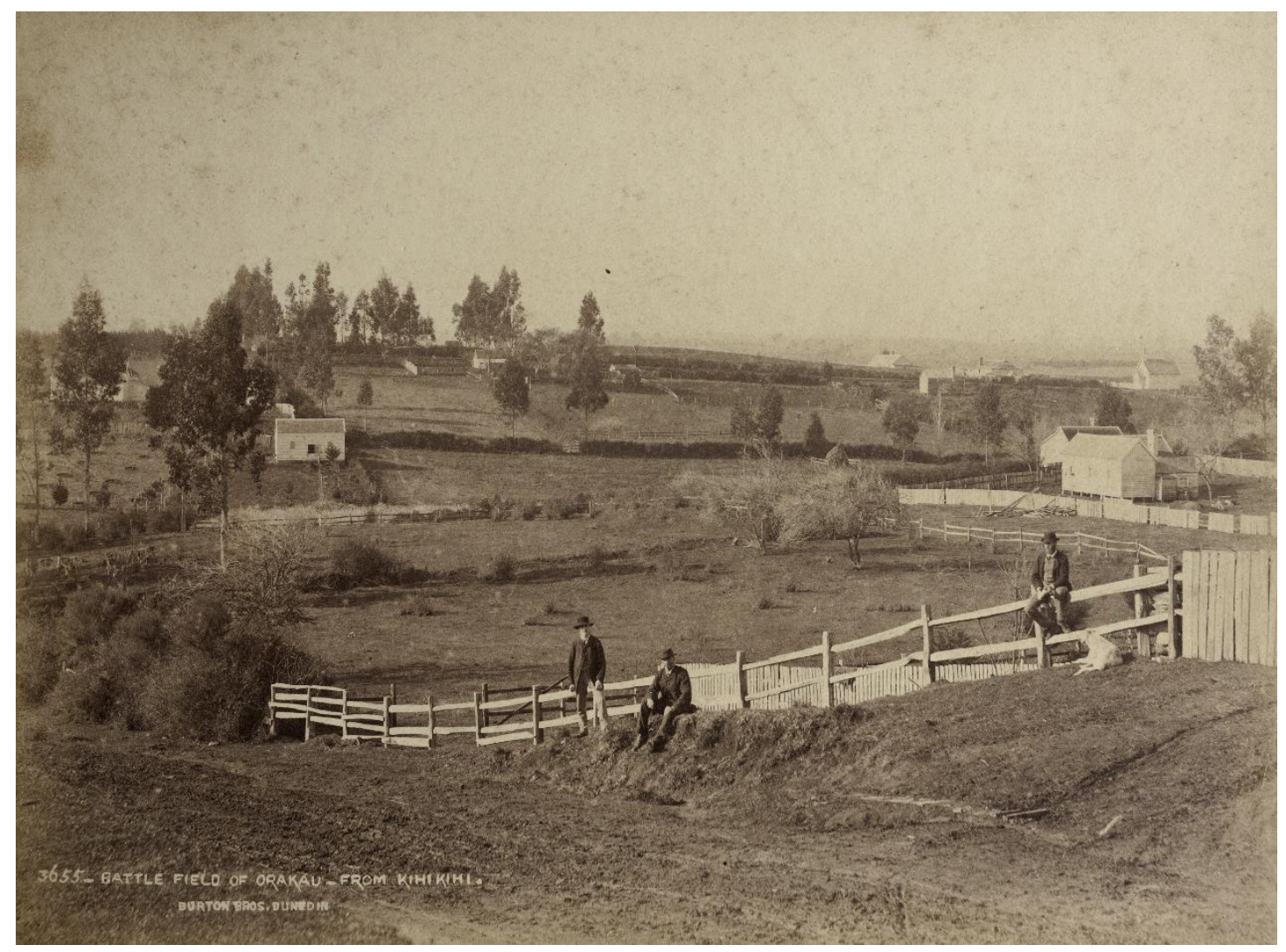

The battle field of Ōrākau from Kihikihi, 1885.This photograph was taken when Cowan was 15 years old, and very likely includes part of the Cowan family farm. Twenty-one years after the battle, the site was greatly altered.

Burton Brothers Inkjet print from original albumen print. Alexander Turnbull Library, PAColl-0585 
${ }^{1}$ I wish to thank Ellen Pullar for her invaluable assistance, the two anonymous readers for the Journal of New Zealand Studies for their very helpful comments, and the University of Otago Research Committee for funding the research on which this article is based.

${ }^{2}$ Eileen was the daughter of Henry Stowell, or Hare Hongi, a noted interpreter and collector of information on Māori, and Mary Robson. P. J. Gibbons, "Henry Matthew Stowell," Dictionary of New Zealand Biography. http://www.teara.govt.nz/en/biographies/3s38/stowell-henry-matthew ${ }^{3}$ Mary Louise Pratt, Imperial Eyes: Travel Writing and Transculturation (London: Routledge, 1992), 6.

${ }^{4}$ Pratt, Imperial Eyes, 7.

${ }^{5}$ Giselle Byrnes, "Surveying Space: Constructing the Colonial Landscape", in Fragments: New Zealand Social and Cultural History, ed. Bronwyn Dalley and Bronwyn Labrum (Auckland: Auckland University Press, 2000), 55.

${ }^{6}$ Geoff Park, Theatre Country: Essays on Landscape and Whenua (Wellington: Victoria University Press, 2006), 113-28, 195-204. "Protecting" land for scenery sat alongside the ongoing land-taking; see David Williams, "Te Kooti Tango Whenua": The Native Land Court 1864-1909 (Wellington: Huia, 1999).

${ }^{7}$ David Colquohoun, “James Cowan,” DNZB. http://www.teara.govt.nz/en/biographies/3c36/cowanjames

${ }^{8}$ James Cowan, Travel in New Zealand. Vol. I The North Island (Auckland: Whitcombe \& Tombs, 1926), 97-8.

${ }^{9}$ Peter Gibbons discusses Cowan briefly under his 'Literature of Occupation' section in the "NonFiction" chapter of The Oxford History of New Zealand Literature in English, 2nd. ed. (Auckland, Oxford University Press, 1998), 62-3. Alex Calder is appreciative in his introduction to an edition of Cowan's Tales of the Maori Bush (Auckland: Reed, 2006), but makes only passing comment in his discussion of how Pākehā have claimed place in New Zealand, The Settler's Plot: How Stories Take Place in New Zealand (Auckland: Auckland University Press, 2011). Jane Stafford and Mark Williams' Maoriland: New Zealand Literature 1872-1914 (Wellington: Victoria University Press, 2006) considers a slightly earlier period but nevertheless does not consider Cowan's early work. In their introduction to a Special Issue on 'Settlement Studies', Alex Calder and Stephen Turner laudably seek to avoid the trap into which too much postcolonial critique falls - it "looks from afar and sees what it expects to see"- and to look instead at, for example, how "colonisers and colonised are mutually transformed in the complexities of encounter and exchange" "Introduction," Settlement Studies: Special Issue, Journal of New Zealand Literature 20 (2002): 7-17; 8. Yet the essays in the Special Issue still seem to revert back to a kind of default mode of dealing with coloniser and colonised which could not readily accommodate the confrontations in which, I argue here, Cowan's work deals. Turner's essay, for example, defines "being colonial" as "taking possession of the place and making it over in your image" "'Being Colonial/Colonial Being" Journal of New Zealand Literature 20 (2002): 39-66; 41.). My objection is not that this never happened - it clearly did, and repeatedly — but that it was not the whole story. The most sustained discussion of Cowan as a writer is in fact by historian Chris Hilliard, "James Cowan and the Frontiers of New Zealand History," New Zealand Journal of History 31, no. 2 (1997): 219-33.

${ }^{10}$ Tales of the Maori Bush (Dunedin: Reed, 1934), Tales of the Maori Coast (Dunedin: Reed, 1934), Hero Stories of New Zealand (Wellington: Harry Tombs, 1935), Tales of the Maori Border (Wellington: Reed, 1944).

${ }^{11}$ The term is Peter Mandler's: "The Problem with Cultural History," Cultural and Social History 1 (2004): 94-117.

${ }^{12}$ Jessica Dubow, “'From a View on the World to a Point of View in it': Rethinking Sight, Space and the Colonial Subject," Interventions 2 no. 1 (2000): 87-102, 88.

${ }^{13}$ Dubow, "“From a View,"” 85, 89.

${ }^{14}$ James Cowan, “Old Rotorua: Legends of the Lakes," Evening Post 18 June 1910; 18 June 1910; 25 June 1910.

${ }^{15}$ Cowan "Old Rotorua," 30 July 1910. 
${ }^{16}$ Cowan, "Lakeland and Storyland: The Charm of a Rotorua Cruise," New Zealand Railways Magazine 6, no. 2 (1931): 27-33.

${ }^{17}$ Michael King, "Introduction," in The New Zealand Wars: A History of the Maori Campaigns and the Pioneering Period, by James Cowan, Vol. I: 1845-64, (rpt. Wellington, P.D. Hasselberg, Government Printer, 1983), vii; Hilliard, "James Cowan and the Frontiers."

${ }^{18}$ James Cowan, Tales of the Maori Border (Wellington: Raupo, 1944): 57; 60.

19 "Opening up Urewera," Evening Post, 6 September 1921, 7.

${ }^{20}$ James Cowan, "Tongariro River," Evening Post, 11 November 1931, 8.

${ }^{21}$ Nigel Thrift, "Steps to an Ecology of Place," in Human Geography Today, ed. Doreen Massey, John Allen and Philip Sarre (Cambridge: Polity, 1999): 295-322.

${ }^{22}$ Edward Fitzgerald, "Ake! Ake! Ake!" The Press, 16 April 1864, 2. For FitzGerald's role as Native Minister, see Edmund Bohan, "Blest Madman": FitzGerald of Canterbury (Christchurch: Canterbury University Press, 1998), 267-69.

${ }^{23}$ James Cowan, The New Zealand Wars: A History of the Maori Campaigns and the Pioneering Period, Vol. I: 1845-64, (1922; rpt. Wellington, P.D. Hasselberg, Government Printer, 1983); James Cowan, The Old Frontier: Te Awamutu, The Story of the Waipa Valley (Te Awamutu: The Waipa Post, 1922). The Old Frontier's publication date is 1922 and Cowan's preface is dated September 1922, but it seems only to have been issued in November 1923: newspapers record its arrival then, and the first reviews appeared in that month. It is very likely that its release was delayed because Internal Affairs, Cowan's employer for the official history, objected to Cowan making a sideline profit from his work in their employment, a practice for which he was fairly well known. For his part, Cowan was paid a salary for the official history, and would therefore not have anticipated royalties, so may have looked for ways to maximise the work for the project.

${ }^{24}$ James Cowan to Hon. G.W. Russell, "History of the Maori War," 28 November 1917. National Archives IA1 1280. 4/2/13.

${ }^{25}$ For example, see the discussions in Michael King, "Introduction," vi; and Chris Hilliard, "James Cowan and the Frontiers of New Zealand History." The most extended discussion of the official history, which usefully documents Cowan's oral sources, is Gregory Wood, "Revisiting James Cowan: A Reassessment of The New Zealand Wars (1922-23)," MPhil thesis, Massey University, Auckland, 2010.

${ }^{26}$ Cowan Papers, MS-Papers-0039-10K, Alexander Turnbull Library.

${ }^{27}$ Gustavus Ferdinand von Tempsky, "Memoranda of the New Zealand campaign in 1863 and 1864," MS-2136-2140, ATL.

${ }^{28}$ Cowan, NZW, I, 352.

${ }^{29}$ Cowan, NZW, I, 365.

${ }^{30}$ Cowan, $N Z W$, I, 365-6.

${ }^{31}$ Cowan, NZW, I, 366.

${ }^{32}$ Cowan, $N Z W, \mathrm{I}, 367$

${ }^{33}$ Cowan, NZW, I, 397.

${ }^{34}$ Cowan, "Preface," Old Frontier.

${ }^{35}$ Cowan to McCormick, 24 October 1939, IA1, 62/110/2, NA; cited in Chris Hilliard, "James Cowan and the Frontiers of New Zealand History," New Zealand Journal of History 31, no. 2 (1997), 219-33.

${ }^{36}$ Cowan, Old Frontier, 7.

${ }^{37}$ Cowan, Old Frontier, 7.

${ }^{38}$ Cowan, Old Frontier, 23.

${ }^{39}$ Cowan, Old Frontier, 35.

${ }^{40}$ And indeed, Cowan's sympathy for the Kīngitanga did not lead him to a critical analysis of some government strategies and more broadly the government interest in propagating war in the Waikato: in the official history, for example, he accepts the unsubstantiated rumours of plots to attack Auckland. Cowan, NZW, I, 239-40. By contrast, see Vincent O'Malley, "Te Riri ki Waikato," in Beyond the Imperial Frontier: The Contest for Colonial New Zealand (Wellington: Bridget Williams Books, 2014), 111-29.

${ }^{41}$ Cowan, Old Frontier, 84. 
${ }^{42}$ Cowan, Old Frontier, 84.

${ }^{43}$ Cowan, Old Frontier, 84.

${ }^{44}$ Cowan, Old Frontier, 84.

${ }^{45}$ Cowan, Old Frontier, 86.

${ }^{46}$ Cowan, Old Frontier, 85.

${ }^{47}$ Lydia Wevers, "Being Pakeha: The Politics of Location," Journal of New Zealand Studies 5, no. 6 (2006): 4.

${ }^{48}$ Cowan, Old Frontier, 85.

${ }^{49}$ J.H.A. St. John, Pakeha Rambles through Maori Lands (Wellington: Robert Burrett, 1873), 76.

Later in chapter 12 of The Old Frontier Cowan records the periodic scares which made life in the area a matter of anxiety through the 70s: settlers were armed, and prepared with plans for hiding and escape. Old Frontier, 86-7.

${ }^{50}$ O'Malley, 125-26.

${ }^{51}$ I discuss a similar example of Cowan's reconstruction of the past in "A Road into Te Urewera," in The Lives of Colonial Objects, ed. Annabel Cooper, Lachlan Paterson and Angela Wanhalla,

(Dunedin: Otago University Press, 2015), 134-39. 